\title{
Porportionalist reasoning in business ethics
}

\author{
PATRICK GIDDY
}

\begin{abstract}
Proportionalist reasoning, found in the Aristotelian Just War theory, moderates the means taken by reference to the intended (moral) end. However, judging acts by their conformity or otherwise to one normative moral end might, in a liberal society, seem an imposition. Against this objection, I argue, with Spaemann, that values associated with the culture of commerce and its ethical theories are a breakaway from the culture of commitment and virtue that is the only possible framework for ethical reasoning. This commitment is unpacked by MacIntyre through the idea of a social practice and its internal goods. Applied to business, it is work itself, normatively conceived, that is the key internal good.
\end{abstract}

Keywords: proportionalism; Spaemann; business ethics; social practices; double effect; moral community; Aristotelianism; MacIntyre

\section{INTRODUCTION}

Proportionalist reasoning, found in the Aristotelian-based Just War theory, moderates the means taken by reference to the intended (moral) end. However, judging acts by their conformity or otherwise to one normative end might, in a liberal society, seem an imposition. Against this objection, I argue, with Spaemann (1996), that the values associated with a culture of commerce and of liberalist ethical thinking are a breakaway from the culture of commitment and virtue that is the only possible framework for ethical reasoning. This commitment is unpacked by MacIntyre (1981) through the idea of a social practice and its internal goods. Applied to business, it is work itself, normatively conceived, that is, I argue, the key internal good. Business ethics is, in part, a matter of seeing how, in a culture of utilitarian thinking, a counter-cultural moral commitment is called for. This becomes further evident when we apply our approach specifically to the contention of Deon Rossouw (2003) regarding the unsuitability of the Aristotelian approach and, in particular, the principle of double effect in business ethics.

My argument can be formally set out as follows:

The foundation for ethical reasoning lies in the attitude of commitment governing one's participation in a moral community.

\section{Patrick Giddy}

School of Religion, Philosophy and Classics

University of KwaZulu-Natal

Author's postal address:

5 St David's Road

Claremont

7708

South Africa

M: +2772779 1056

E:jpgiddy@gmail.com
Patrick Giddy is a senior research associate in philosophy at UKZN. Recent publications indicate his current areas of research: religion in a scientific and secular culture (2011; Why theology can and should be taught at a secular university, Journal of Philosophy of Education 45); ethics (2012; More than tolerance: Ethics for a multicultural society, Synthesis Philosophica 54); and countering a global philosophical 'autism' (2013; Can African traditional culture offer something of value to global approaches in teaching philosophy and religion?, Acta Academica 45). 
But modernity and the culture of commerce break with all traditions of such participation, in which persons are 'connected in' to common forms of social life.

So authentic business ethics will form part of a challenge to this culture of modernity and commerce; it will take productivity, not as the 'bottom line', but as limited by the whole range of values involved in the critical social participation that furnishes the content of the end by which the proportionality of the means taken is assessed.

The non-trivial nature of the first premise is only apparent in the context of a culture that assumes no such commitment as a given. The following section argues that this is indeed the case in the dominant global culture of commerce. I explain (Section 3) what, in contrast, the Aristoteliantype proportionalist reasoning in ethics amounts to. I then turn, in Section 4, to Spaemann's argument that no subsequent sense can be made of ethical obligations if one has first assumed that individuals have contractual ties only (as is the case, for example, from a commercial perspective). The ethically foundational commitment to respecting persons as fellow participants in a moral community is further unpacked, in Section 5, through MacIntyre's notion of a social practice as framing our contemporary understanding of the virtues. This 'sociological' rather than metaphysical re-interpretation of the Aristotelian approach also answers the typical liberalist objection to any form of communitarian ethics as entailing an arbitrary prescriptive limiting of individual choice of lifestyle. I conclude (in Section 6) that, applied to the world of business, proportionalist ethics challenges the dominant paradigm of commerce, and this is illustrated through a discussion of Rossouw's objection to doubleeffect reasoning in business ethics.

In a speech to the Centre for Social Justice in 2012 Jon Cruddas, the new policy guru of the British Labour Party, argued that our choice at the level of ideas is between a politics of utilitarianism and maximising self-interest, and the politics of Aristotle and sociability. This paper can be seen as an attempt to unpack, for the case of business, what is meant by this, and how it could be defended.

\section{ARISTOTELIAN ETHICS IN THE CONTEXT OF MODERNITY}

Business ethics is a latecomer on the scene of the contemporary world of work. Keynes noted that, for the moment, "fair is foul and foul is fair" (quoted by Schumacher, 1973:24). And Adam Smith, reflecting the new culture of self-regarding competitive individualism, thinks of human dignity as tied to merit (in a commercial sense). Another person merits my regard if they, in turn, benefit me. Their dignity would be taken away if I took regard of them out of sheer benevolence. It is "not from the benevolence of the butcher, the brewer or the baker, that we expect our dinner, but from their regard to their own self-interest. We address ourselves, not to their humanity, but to their self-interest" (quoted from The Wealth of Nations by Kwant, 1969:47). "Nobody but a beggar chooses to depend chiefly upon the benevolence of his fellow-citizens," Smith adds, comparing the beggar pleading for a handout to the antics of a dog before its master's table. In this outlook, any appeal to our natural connectedness with others has gone, obliging us because we see ourselves and our identity as bound up with those of others. Your worth comes from your contribution to the economic system. Self-regard, it is supposed, generates the distribution of fair rewards for merit through the invisible hand. ${ }^{1}$

However, the unjust consequences of this (not everybody is in a position to trade) are soon too severe to remain unnoticed, and principles are stipulated, which, because of 'ethical

1 Amartya Sen (2009:186-187) objects to the frequent use of this quote to critique Adam Smith, and draws on Smith's The Theory of Moral Sentiments to show the economist acknowledged motivations other than selfregarding calculations. 
considerations', should limit our otherwise unbounded entrepreneurial actions. Unlike the other factors of production (textbooks tell us these are, in addition to labour, land, capital, and the manager's own creative input), employees merit special regard. This is because persons in general, employed or unemployed, have, we say, certain properties (rationality, for example), which entail rules moderating our supposed default attitude to the world as an object for our (self-regarding) calculus. They have rights, some of which may be legally (or professionally) enforceable. Businesses do well to show that they are abiding by these rules. Committees are set up to check on this. In order to make sense of the codes of conduct, business managers draw on the expertise of the philosophical community. The ethical theory that accords best with the culture of commerce is that of utilitarianism; the Kantian ethics of principles is used to ground the codes of ethics ameliorating the consequences of considerations of utility. These two approaches get the most attention from the world of business. For both of these, the starting point is the value of autonomy, trumping any ethically significant social relations. It is this idea that the proportionalist approach throws into question.

As is well known, Bentham was sceptical of this move to human rights, calling them "nonsense"; Amartya Sen (2009:355ff) notes the point that, whether fictional or not, it might nevertheless be effective as rhetoric. Be that as it may, the idea of foundational rights or principles arose, I suggest, because the traditional ethical narratives were thrown into disarray with the coming of the modern economic order. Stephen Toulmin makes this point eloquently, quoting Donne:

'Tis in all pieces, all cohaerance gone; All just supply, and all Relation; Prince, Subject, Father, Sonne, are things forgot, For every man alone thinks he hath got To be a Phoenix, and that there can bee None of that kinds, of which he is, but hee. (in Toulmin, 1990:65)
The framework for ethical reasoning in a society without 'coherence', that is, a society without a sense of how one 'binds in', as father, son, educator, and so on, is bound to be problematic. As is the case with neo-Aristotelian Alisdair MacIntyre, the values associated with the culture of commerce that has dominated modernity are seen by Robert Spaemann as a breakaway from the framework of loyalty and commitment (and virtues) that, it is argued, is the only possible framework for ethical reasoning (see also the wide-ranging argument of Mary Clark (2002, esp. Chapter 9)). This amounts to a critique of the whole commercial culture characterising modernity, as made clear in Zaborowski's (2010) book-length account of Spaemann (subtitled Nature, freedom and the critique of modernity).

The recourse to rights suits the (post-traditional) individualist culture of commerce. Rights, it is usually said, pertain to entities (human beings) simply by virtue of their possession of certain properties, and not because they conform to certain models of behaviour embedded in the ethical traditions. However, Spaemann (and, similarly, Frankfurt, 1993, and Tugendhat, 1993) argues that it is only in the light of our prior commitment to a moral community embodying such models that ethical reasoning of whatever kind makes sense. This commitment needs to be explicitly drawn upon by the interlocutors as a starting point, something which the proportionalist approach compels. For the specific content of the commitment supplies the content of the end in terms of which the means are judged proportionate or not. (As a first step in unpacking this idea, one might consider how a footballer's commitment to the nature of the game, and thus to the other participants, determines the meaning of 'excellence' in this particular social practice, excluding 'diving' as a disproportionate means to the intended end, or, for that matter, biting an opponent's shoulder.)

I judge Spaemann's argument to be convincing, but I believe that it needs to be complemented by MacIntyre's re-presentation of the virtue approach to ethics, if it is to be convincingly 
applicable to our own age. I now give a brief account of why this is so. Aristotle thinks of ethics as an enquiry of how best the agent, set on leading a good life, can discern what the appropriate means are to achieve the goal. Young or immature people, Aristotle claims in Book 1 of the Nicomachean ethics, are, for this reason, not good students of ethics. They are unlikely to have sufficient maturity for this kind of commitment, but the study of ethics will greatly profit "those who desire and act in accordance with reason" (Ethics, 1095). We can think of the culture of commerce as typifying this kind of moral immaturity: the agent typically acts for reasons of monetary gain, and not at all for reasons to do with the discernment of 'the good life', understood not subjectively but as eudaimonia, living well, in a fulfilling way.

In contemporary culture, in contrast to the Aristotelian picture drawn above, the term value has acquired a non-moral sense, simply referring to whatever ends or goals are chosen by the agent. Values are subjective. Similarly, in business practices, the end is thought of as extra-moral, and ethical principles come into play only when one seeks to moderate the practice. For example, one might think, as does Deon Rossouw (2003:244), of the end of business as "increasing value", and the contract between manager and shareholders as relatively independent of any particular larger moral narrative. In contrast to this, Spaemann's approach, with its grounding commitment to the equal participation in our community of all persons, industrialists or beggars, could simply be seen as pertaining more to a pre-modern culture that was the background to the classic formulation of Aristotelian-type ethics. For this reason, I find useful MacIntyre's (After Virtue, 1981, Chapter 14) 'sociological' re-description of virtue ethics in a way that is more in tune with our post-metaphysical age, and assumes only social practices - such as the professions - as background.
For a number of years, the Aristotelian virtue approach to business ethics has had its champions (for example, Catacutan, 2013, who mentions a series of recent publications), and the link between building character and business effectiveness has also been articulated in a popular way by writers such as Stephen Covey (2004). We even have a hint in a popular textbook of how the virtue approach to ethics is misunderstood if simply placed alongside other ethical theories or frameworks focusing, as it does, not on actions per se (as they do), but more on character (Velasquez, 2006:109). An objection could be raised, however, concerning cases of tough choices for the business manager: a set of principles or a code of ethics seems to provide a way through this, while 'doing the virtuous thing' does not as it is too vague. In response to this, I put forward the idea, underemphasised in Aristotelian accounts, of proportionalist reasoning in ethics, to which we now turn.

\section{PROPORTIONALIST REASONING IN ETHICS}

Proportionalist reasoning is most widely known through the Just War principles, and, in particular, the precept that the means taken should be proportionate, or not unreasonably disproportionate, to the intended end. The principle of double effect (discussed below) explains how what may seem to be prima facie wrong acts - killing another human being, or firing a worker who has children at home to feed and educate - might indeed be the morally good thing to do when judged to be proportionate to the end. The bad effect is foreseen, but not directly intended. (For Aquinas' discussion, see Summa Theologiae IIa IIae, Q.40, Art.1 and Q.64, Art.7.) The basic idea is summarised by Knauer: "One may permit the evil effect of his act only if he has commensurate reason for it" (quoted in Kalbian, 2002:13). The tools available in this (Aristotelian) ethical tradition for thinking through these tough problems should, I argue, be more widely known. 
What matters in this Aristotelian approach to ethics is not only what is achieved, but also what the intention is behind the act. For example, among the virtues are courage and generosity; courage is a species of aggressiveness, and generosity can be shown by liberality in giving money. "But," remarks Aristotle, "anyone can get angry, that is easy, or give or spend money; but to do this to the right person, to the right extent, at the right time, with the right motive ... that is not for everyone, nor is it easy" (Ethics, Book 2, 1109). The intention or the motive determines, in part, the character of the act. Is the giving of the money, for example, an act of bribery (intending the crime, thus a vice) or else unwitting criminality (the goods you buy are stolen, but you don't know this), or, finally, an act of generosity towards a person in need? In the religious tradition that Aquinas inherited, moral laws seem to be absolute, but, in line with his philosophy, Aristotle argues that intention is crucial. An act of killing may be murder, culpable homicide, or an act of courageous and legitimate self-defence. According to the principle of double effect, an act may have, in addition to its intended effect, a further effect that is not intended, but may be foreseen. The agent (soldier, business manager) may foresee that his act will lead to the other person's death (in the case of the soldier) or job loss (in the case of the manager), but does not directly intend this; rather he intends a just victory (and a peaceful, reconciled society or community of societies), or else the continued health of the company.

What demonstrates a correct intention, in the justified war approach, is the willingness of the agent to adhere to the demands that the end aimed at is indeed a just one, that innocent people will not be deliberately harmed, that the action is taken as a last resort (for example, other means of saving the company have been tried), and that there is a reasonable chance of achieving success. Furthermore, there must obtain the requisite willingness to suffer the consequences (defeat, perhaps) if these conditions are not met. (As I will argue below, the ethical business manager, and, likewise, the owners of the company, must have the necessary willingness to suffer a loss of profits.) This care to discern whether or not these conditions pertain, will confirm the intention as good that it truly is justice that is aimed at; justice is what motivates the agent. In the final analysis, we would hope that protagonists consider their actions in the light of the common social world shared with all those affected by their actions. In the justified war approach, there is an enhanced sense of those necessary moral values bound up with the humanity we share in common with our adversaries.

This proportionalist ethical reasoning, foregrounding virtues and the quality of the agent's character, is an Aristotelian approach to ethics, as Catacutan (2013:65) also points out. For an act to be one of virtue - and not, for example, simply one of skill - it has to be undertaken for the right end. Thus - to invoke the Just War theory - the acts of a mercenary are not strictly speaking acts of virtue, i.e. courageous, precisely because of his or her lack of appreciation of this value: the mercenary, as Aquinas (1993, para.593) argues, has in mind the end of monetary gain, not the just and peaceful coexistence of the protagonists. The killing of another human is a disproportionate rather than a proportionate means to the end of monetary gain. Just as the combatant has to appreciate what the fighting is for, so too the ethical business manager has to understand what work is for. Clearly, there is a shortterm goal in any action envisaged: the unit has to take and secure a bulwark on the hill, for example, or the manager has to break even, or increase profits. But only if the end is understood in virtue of which - to stick with the case of war - the fighting is taking place, will the soldier appreciate that, for example, killing is forbidden if the enemy surrenders, or that civilians may not be deliberately targeted. Analogous restrictions pertain to the actions of the business manager. 
This ethical reasoning only makes sense against the background of some moral vision. In Aristotle's normative Athenian culture, the moral vision had purchase, and, when formalised, it could be seen (as it was by Aristotle) as a particular view of human flourishing, flourishing of what we are by virtue of our shared human nature. As is well known, this vision excluded women and slaves from the moral horizon. This counts against this approach, but, I argue, does not preclude a critical appropriation of the Aristotelian framework. In both the account of Spaemann and that of MacIntyre we find a shift in emphasis, from a foundation in one, fixed set of propositions about an ideal of human living, to the act of commitment to participation. Ethical living furthers that participation through acts of prudence, that is, acts judged proportionate to the end. The Just War principles, in particular the principle of double effect, allow one to see how difficult decisions can be made taking into account the harm that may result from those decisions. This is central to good business ethics and management policy.

Various objections to proportionalist reasoning are discussed by Bernard Hoose in his book, Proportionalism. The American debate and its European roots (1987). For Germain Grisez, moral objectivity has to rest in something other than simply "what seems to one to be good", for then no one can ever be said to have done anything wrong, because, clearly, everyone always does what he or she thinks is the best (Hoose, 1987:56-57). A second objection sees proportionalist reasoning as watering down moral principles that should be taken as absolute, precisely in order to counter utilitarian ethics. This is the thinking of, for example, John-Paul II (Veritatis Splendor, 1993, para.90), who argues that the proportionalist approach forms no part of the broad Aristotelian/Thomistic moral tradition (see Kalbian's (2002) useful article, Where have all the proportionalists gone?).

In answer to the first objection Hoose (1987, Chapter 3) points out that we can distinguish what is morally right (the (objectively) right action is done) from what is morally good (the right action is taken with the right motive). There is, then, a place for codes of ethics and moral rules, determining morally right action, within the framework of proportionalist reasoning. A remarkably healthy teacher who does the right thing in not fraudulently claiming the allowable number of days of sick leave simply because of a fear of being found out might grow in appreciation of how the students are disadvantaged when the teacher is absent, in other words, the reason for this particular ethical code.

In answer to the second objection, that proportionalism slips into a kind of utilitarian thinking, Hoose points out that there is a fundamentaldifferencebetween proportionalism and any form of consequentialist reasoning. Given the assumption that no common values can be taken as given, that value is created by the sum of the interests of atomistic individuals, the typical retort to foreseen but not directly intended negative effects is something to the effect of 'you can't make an omelette without breaking some eggs'. However, there is no way here of moderating more or less how many eggs it would be justified to break. Hoose (1987:92) mentions the well-worn example of a lynching mob in the southern United States that threatens to kill a number of people unless the culprit is brought to justice. They will be satisfied, the sheriff realises, if a certain black man is taken to be the culprit and executed. Consequentialist reasoning would conclude that the lives saved would justify this action. Rule utilitarianism could, however, provide an argument against this counter-intuitive conclusion, by pointing to the negative effects of the lynching on the institution of justice. Hoose remarks here that, of course, the institution (practice) of criminal justice would be undermined by this action, but that proportionalist reasoning of the kind we have been discussing does not have to mention more than the fact that the suffering and death of the innocent man is an evil sufficient to deter 
one from attempting to avoid the likelihood of other deaths. Because of one's moral identity, the means taken matter from the point of view of the agent concerned with his or her integrity. Being responsible, one has to answer to the norm of one's shared humanity.

I now intend to strengthen the case for proportionalism by (a) reviewing the way Spaemann undermines an ethic of principles taken out of the context of an assumed normative connectedness to others, and (b) drawing on MacIntyre's notion of a social practice as a way forward for business and management practice to be brought into the sphere of ethics.

\section{SPAEMANN ON THE FOUNDATIONAL COMMITMENT TO RESPECTING PERSONS}

Spaemann (1996) argues that no subsequent sense can be made of ethical obligations if one has first assumed individuals with contractual ties only (as is the case, for example, when they are considered from the point of view of the production process). He gives a number of reasons for saying that we cannot delineate certain properties (say, rationality) that qualify a being for respect as a person, as a 'someone', and thereafter adopt the attitude of respect for them (see also Spaemann 2006). Human rights cannot be invoked, by itself, as the starting point of ethical reasoning (it can, of course, be the starting point of legal reasoning - certain human rights may be enshrined, legally, in the constitution). ${ }^{2}$ Firstly, he draws on the phenomenology of the mother-neonate interaction. "No mother," he argues, "acts with

2 Spaemann contrasts his approach with that of Peter Singer (for example, 1999, esp. 89) who, carrying on the Lockean tradition, separates personality (as a property) and human being. Since, for Singer, we give value to persons, and personhood is a set of properties such as the capacity to be conscious of being hurt, we should consistently give value to those existents that have these properties (as, in our example, pigs do, but not newborn infants.) the intention of manipulating 'something' in a way that someday will make a 'someone' out of it" (1996:467). ${ }^{3}$ A related point is that of the inappropriateness of the term potential persons. The person does not begin after the human being begins, nor does it cease before the human being ceases. To be sure, we only say 'I' after a certain time. Yet, "we do not say, 'then or there something was born, from which I then came to be'. I was this being. Personality is not the result of a development but rather already the structure of a unique kind of development" (1996:471, italics added). The ethical call on us, resulting from encountering persons, is there, in other words, by nature, not because we recognise certain achievements. ${ }^{4}$

Spaemann (1996:468) further notes that the apparent lack of intentional acts in someone does not immediately allow us to conclude the absence of personhood. A mentally ill person might give his or her acts a meaning we can't recognise, but we continue to look for what they intend, we assume a certain degree of rationality in their acts. Membership recognition is ethically foundational, a question of identifying with the other in an act of commitment. A supporting point is that the unconditionality of ethics is not derived from some abstract or general rule that is then applied to particular cases. "The claim of persons to unconditional respect is rather perceived primarily and fundamentally as a claim that comes from a particular person or from several particular persons" (1996:473).

For our purposes the more pertinent of Spaemann's reasons has to do with the distinc-

3 In his phenomenology of early childhood, The look, the body and the other (1975), Wilfried Ver Eecke notes that, in the case that the neonate is treated as a 'something', say, by a carer, the result is the retarded status named 'hospitalism'. See, at greater length, John Macmurray's Persons in relation (1960).

4 Thus, Menkiti (1979) is off the mark, in terms of this approach, in approving of the African traditional attitude to the human person as constituted by the community, which confers personhood on the infant. 
tion he draws between between someone and something. How do we perceive the incapacitated (those too seriously impaired to coordinate their movements)? Not as animals of a unique type, but rather as 'patients', as infirm. They are persons needing help. We search for a cure, to help them assume their place in a community reserved for them. In fact, our growth in understanding of exactly what personhood means will depend on the way we deal with such human beings.

Spaemann suggests this thought-experiment: consider a being born of humans but exhibiting no indication of identifiable practical and theoretical intentionality. On the other hand, it also appears quite healthy, and moves normally in the world. In other words, it is not ill. We would judge that it does not belong to humankind; it is not a person. By contrast, the mentally infirm do belong to humankind. In fact, they allow the meaning of the moral community to shine forth: "Love and recognition of a human being are addressed to that being itself, not to its properties" (1996:469). It is the case, however, that we perceive what this kind of being is through its properties, but not because of them. Someone whom one loves, for example, will always have some special characteristics, charming properties that initiate the love, but the love itself goes beyond these. Because the infirm have few of these charming aspects, "it becomes clear in an exemplary manner that, in the human community of acknowledgment, it is really the acknowledgment of selfhood that is at stake and not merely an esteem for useful or pleasant characteristics" (1996:469). This is the authentic foundation for our respect for persons. It is not at all that the moderating vision of positive human flourishing judges and excludes individuals who fail to reach the mark. This also points to the importance of our culture's attitude towards the non-productive members of society. It throws into question a culture in which an increase in production is the bottom line, an idea highlighted in Mary Clark's (2002, esp. 311ff) critique of modernity.
Spaemann's approach clearly falls within the Aristotelian 'human flourishing' approach to the foundations of ethics. Humanity can't be a legally defined community in the sense of a closed shop. The unconditionality of the ethical demand cannot "depend upon the fulfilment of some qualitative condition, about which others decide who are already acknowledged members of the community of rights and law" (1996:473-474). Our starting point in ethics is a commitment or intention to extend and deepen, for our own case, but in a way that takes regard of others, our already given membership of a moral community. By emphasising the foundational attitude of relating to someone, rather than a utilitarian-type dealing with something, Spaemann heads off the danger that proportionalism ultimately amounts to a utilitarian ethic.

I think Spaemann's extended argument is, so far as it goes, convincing (see Madigan's extensive commentary, 2010). However, could one not object that Spaemann is simply expressing a preference for a pre-commercial kind of society, something unworkable in our own cultural situation? Is he not, in fact, a kind of ethical Luddite? Furthermore, does his approach (or that of any Aristotelian), as argued by Michael Smith (Smith, 1994:91), amount to one group, a 'mob' imposing their vision of the human good on another section of society whose agreement they do not have? Kohlberg, as Catacutan (2013:65) points out, describes character education programmes aimed at teaching virtue as forms of indoctrination. ${ }^{5}$ Rights, on the other

5 To the latter objection, Catacutan (2013:65) retorts that virtues are only formed through freely chosen acts, where the agent sees the point of the act and consents to it. Simple, unthinking repetition for reasons of wanting to conform would not bring about the requisite development of character. This means that the agents must appreciate for themselves the normative picture of human flourishing at work in this kind of ethical deliberation. The question remains unanswered by Catacutan why any particular individual should consent to this particular ethical framework in the first place. 
hand, apply to individuals regardless of their insertion into normative moral communities, an argument also given by Richard Rorty (see Ian Hunter, 2000). ${ }^{6}$ No common moral vision providing the standard for judging the proposed action as proportionate or otherwise, as an act of virtue or of vice, is thought possible. The following section, responding to this, outlines MacIntyre's retrieval of the Aristotelian tradition in ethics, through the uncontroversial notion of a social practice, committing participants to objectively determined ideas of virtue and of quality of character.

\section{INTERNAL GOODS OF BUSINESS IN TRANSITIONAL SOCIETIES}

MacIntyre, like Spaemann, finds the rightsbased ethics of principles unconvincing, and even incoherent (1981, Chap. 2 and 3). There is no need to rehearse his well-known and muchanthologised argument that this dominant approach amounts simply to a version of emotivism without objectivity. ${ }^{7}$ We are concerned here only with the way in which he has reexpressed the Aristotelian approach in a 'sociological' way more easily appreciated in a post-metaphysical culture such as our own. He links virtues to skills, and publically recognised achievements of human powers, as they would

6 This is an argument used by liberalists (for example, Tony Oyowe, 2013) against African traditional ethical culture and, in particular, the idea of $u$ buntu, a normative vision of what human persons can and should grow into. It is argued that those persons who do not conform to this vision (say, typically, homosexuals who resist the norm of taking a spouse) would then be excluded from the community of those accorded value.

7 To some extent he is picking up on the point made earlier by Elizabeth Anscombe (1958:32) about the "mere mesmeric force" of the "moral ought" found in the categorical imperative of principle-based ethics. MacIntyre's full critique of the latter approach is well summarised and explained in Garcia's paper, Modern(ist) moral philosophy and MacIntyrean critique (2003). have been in the classical Greek understanding. What is uncontroversial in that society, as in ours, is the existence of social practices: large-scale cooperative activities whereby goods internal to the practice are achieved and developed (MacIntyre, 1981, esp. 181). Examples are the medical and legal professions, sports, and family life. In each case, there is an ideal of objective excellence. However difficult it is to specify the content of a good teacher or a good parent, this is not at all simply a subjective matter.

The crucial term here is internal. What defines an activity as a social practice (rather than simply getting something done in general) is that the means taken to achieve success in the practice are in part definitive of (and not tangential to) a successful enactment of the participant in the practice: they are the internal goods of the practice. The contrast is with goods external to the practice. So, the good internal to the medical profession is that of health, while the external, or incidental, goods attaching to the institutions necessary to the practice of medicine (hospitals, administration, professionalbodies) are typically those of promotion, salaries, and so on. If there is a widespread tendency of practitioners to put the external goods ahead of the internal goods, the practice is in danger of being corrupted. This is obviously an important point to keep in mind in an increasingly commercialised world, often destructive of normative traditions. For a local example from the music profession, see Giddy and Detterbeck (2005); similarly, from the point of view of the banking profession, see Carney (2014). ${ }^{8}$

8 Mark Carney, Governor of the Bank of England, describes the importance of capitalism being inclusive: "To build this sense [...] business ultimately needs to be seen as a vocation, an activity with high ethical standards, which in turn conveys certain responsibilities. It can begin by asking the right questions. Who does finance serve? Itself? The real economy? Society? And to whom is the financier responsible? Herself? His business? Their system? The answers start from recognising that financial capitalism is not an end in itself, but a means [...]" (Carney, 2014). 
What is clear is that the conditions necessary not to fall into the dumbing down of all values into one, success in a monetary sense, are precisely the traditional virtues of practical wisdom, fortitude in the face of difficult choices, self-control in the face of easy options, and justice to the task at hand. The integrity of social practices - medicine, education, the legal system, police, business - seems to rely on an overarching moral narrative envisioning some such normative idea of human flourishing that has purchase among practitioners, and which reinforces their commitment to hold to and expand their appreciation of the internal goods of their particular profession. It is within that moral narrative that the status society accords to the professions makes sense - because of the ends brought about, which are valued by participants who identify themselves through the narrative or particular culture: learning, health, religious piety, justice, social order, and so on. It is notably in societies in radical transition that the presence, or the absence, of such moral narratives, the background to professional ethics, is of particular concern.

Consider the case of a history of injustice. Simply granting formal rights to individuals where these did not previously exist will be inadequate, and will not go the distance in supplying a framework for thinking through tough ethical questions in business. The overarching normative narrative has to be recaptured. The point about injustices is not simply their physical effect, but the fact that they also embody a symbolic message from perpetrator to victim. Apart from its effect, the action also has an expressive meaning.

They are ways a wrongdoer has of saying to us, 'I count but you do not'; 'I can use you for my purposes', or 'I am here up high and you are there down below'. Intentional wrongdoing insults us and attempts (sometimes successfully) to degrade us [...]. (Jeffrie Murphy, quoted in Bennett, 2003:131)

One reaction is to feel that what we need in order to have our status restored is to diminish the status of the perpetrator. That would be one popular understanding of retributive justice. In an interesting article, useful for our purposes, Christopher Bennett argues that, contrary to the views of, for example, Bishop Desmond Tutu, the attitude of forgiveness is not a substitute for retributive justice, but rather one which can restore the possibility of ethical reasoning within the moral community.

The moral community is a social group constituted by the shared commitment of its members to certain values, to a certain way of regarding and treating others, to certain ends. To recognize an agent as a member of the moral community is to see them as capable of understanding and responding appropriately to these values; it is to have an expectation that these values will weigh with them [...]. (Bennett, 2003:132)

Even if the attempt to diminish the perpetrator's status is not the correct action, something in our relationship has to change if we are not to falsify the grounds of moral community, namely the assumed commitment of its members to those common values, a commitment now thrown into question.

In our own South African case, for example, Eusebius McKaiser has argued that, because of the continuing scars of apartheid, "societal self-making must still take place in order to deal with the gap between our normative ideals and our lived realities" (reported in Woermann, 2012:89). The attitude of forgiveness would recognise the blameworthiness of the misdeed, but see the perpetrator's wrong as "an aberration, his distancing himself from correct values as merely temporary" (Bennett, 2003:133). The act of forgiveness impacts back on oneself, and restores one's ability to see oneself as not under threat of having one's status undermined by participating in the moral community. That was not, one says in effect, what the fellow perpetrator really intended. If our values are derived from the moral tradition, and not from our free contractual obligations, then membership of that moral tradition cannot 
be a kind of club. It must precede our attitudes of approval or disapproval of others. There can be punishment, but it will not be an act of taking away their status in order to restore ours. The correct punishment will be judged in terms of the values it achieves, let us say, for example, restoration of what has been stolen, or reform of the wrongdoer.

The attitude of forgiveness is usually taken as supererogatory, doing more than is required from a moral point of view. However, what we have been saying above about ethical reasoning would seem to make such an attitude more central. This is because forgiveness (in the sense we have put forward) is, in certain situations, constitutive of the only possible framework in which ethics makes sense: a commitment to an inclusive community (see also Giddy, 2010). Honouring contracts or respecting rights cannot do the job. In proportionalist reasoning, as we have seen, what is meant by the agent is a central consideration, how they see their participation in the moral community, and the expressive meaning of their action; but this is not the case in principle-based approaches to ethics or in the utilitarian calculus. These considerations are alien, also, to the contemporary paradigm of competitive work, and might seem out of place in debates on business ethics. However, in a case such as that of South Africa, it is clear that reference needs to be made to the kind of framing of our identities expressed by the Truth and Reconciliation Commission, as well as in policies such as BEE.

\section{BUSINESS ETHICS AND THE PRINCIPLE OF DOUBLE EFFECT}

We are now in a position to apply these ideas to the sphere of business. Participation in a moral community (expressed, as argued above, through the moral narrative of the particular society in question) is the foundation for ethical reasoning. This furnishes the content of the end by which the proportionality of the means taken is assessed. Repeated courses of action, responsibly assessed in this way, builds habits of character or virtues. However, the emergence of modern civil society - this is the second premise of our argument - went hand in hand with a break from any tradition in which persons are 'connected in' to common forms of social life. Only contracts freely entered into by autonomous individuals were now seen to have legitimate binding force (but see also Jacobs, 1994, for contemporary evidence of a countervailing pre-modern cluster of values). The tendency in the modern period is to begin from the fully self-secure and atomistic individual, the "phoenix", in John Donne's words, arising fully independent from the ashes of the past, without any natural relations to others. We can conclude that bringing ethics (as we have made sense of it) into spheres of civil society, such as business, will constitute a challenge to such a culture: it will take productivity not as definitive of human dignity, but rather as limited in proportionalist reasoning, the starting point of which is the ethically valued community of persons.

The purpose of business, from an ethical point of view, cannot be, as Rossouw (2003:239) has it, that of value creation, where value is defined in terms of the sum of individually conceived interests (those of 'stakeholders'). This idea of what work is about, aiming at material wealth, as Weber noted, used to be thought of as, importantly, a secondary goal, but has become, under the conditions of modern culture an "iron cage", gaining "inexorable power over the lives of men" (The Protestant Ethic and the Spirit of Capitalism, in Gini \& Sullivan, 1989:54) By this, he means that modernity makes a decisive break with the traditions in which work is framed by values and is thought of as a commitment or 'calling' - a sentiment echoed in the US Catholic Bishops' document on work (1986). In an early article, MacIntyre (1979) questioned whether ethics makes any sense at all in the world of business (Corporate modernity and moral judgment: Are they mutually exclusive?). He highlighted a perception that, in business, the agent must be prepared to turn his moral 
intuitions on and off in accordance with whether or not they serve the purposes of the business, being cooperative and fair in his dealings within the corporation, but employing a means-ends utilitarian calculus in which results alone count in dealing with competitors or even the public in general. ${ }^{9}$

In order to qualify as having possible ethical merit, the business enterprise would then have to conceptualise itself as a social practice, which is to say it would make sense to distinguish between the internal, constitutive goods of the enterprise and the goods of the institution (salaries, profits, and so on), thus, no 'iron cage' restricting the motives of employees to that of material wealth alone. For example, a very financially secure football team need not be the most excellent, and the same with a university, where success in securing funding and in branding does not equate to excellence in terms of the internal goods of the practice. ${ }^{10}$

The key internal good of business is work, normatively conceived of. That would mean upholding the dignity of labour and its constitutive role in the growth of the person and in the well-being of the community. The distinction would be with productivity, which would take into account neither the intentions of the agents, how they conceive of what they are doing (appreciating the values associated with that kind of business, and its contribution to the common good), nor (within legal limits) the means taken by them. ${ }^{11}$ The challenge

9 Along similar lines, see Solomon (1992), the many voices on this topic in the Templeton Foundation booklet (2008), and Deidre McCloskey (2006).

10 Something not always appreciated by university authorities. When I pointed out this distinction in a newspaper op-ed article (UKZN has lost its way, The Mercury, August 2013) for the case of my own university, I was summoned to appear before the deputy vice-chancellor "to explain yourself", as she put it.

11 Googling "work ethics films" yields many examples (some based on true events in the business world) that bring our attention to the to business is to treat the employee not as a 'something' (a factor of production), but, in a counter-modern move, as a 'someone' (to use Spaemann's terms), in other words, as 'bindingin' to a morally significant community. The manager's moral commitment would be to standing up for the employees, negotiating the economic and other external pressures on their behalf, in the light of the standards of excellence associated with the internal good of work. Any means taken by the manager must be judged in terms of its proportionality or otherwise to this good, rather than thinking simply of the private good or profitability of the firm. This is pointed out by the authors of the U.S. Catholic Bishops' Pastoral Letter on the U.S. economy, Economic justice for all (1986, para. 97). Work is not just self-centred but oriented to the public good. This is the case for blue-collar workers, managers, homemakers, politicians, and all others. The definitive values of work have to be recognised as internal to commercial activity, making it morally praiseworthy and not, for example, neurotic. The prime responsibility falls on managers. "Persons in management face many hard choices every day, choices on which the well-being of many others depend. Commitment to the public good and not simply the private good of their firms is at the heart of what it means to call their work a vocation and not simply a career or job" (1986: para.111). Marx's critique of work in a capitalist economy as alienating the worker from a flourishing life together with others (Marx, 1964, esp. 106-119) has, arguably, a similar intent, although leaving

dangers of thinking of business in terms of productivity alone. I will mention just two: the tale of a cut-throat estate agency business in "Glengarry Glen Ross" (1992, Dir. J. Foley, from the play by David Mamet), and that of deceptive marketing in "The Joneses" (2009, Dir. D. Borte), playing on the default trust that neighbours have that families are more or less what they appear to be. The actions taken by employees exclude the possibility of building community: the work, in spite of raising productivity and hence 'successful', would, other things being equal, be judged to have no merit at all. 
out, as I have argued elsewhere (Giddy, 2000), the virtue dimension.

The general idea in the Aristotelian approach to business ethics has been well expressed by R. Solomon (1999) (similarly, by Brytting, 2000, and also Verstraeten, 2000). In rethinking the company as a 'community', he writes: "The Aristotelian approach begins with the idea that we are, first of all, members of communities, with shared histories and established practices governing everything from eating and working to worshipping" (Solomon, 1999:43). This, he points out, shifts the idea of what counts as success for the corporation, in particular downgrading the role played by the shareholders' interests. "Shareholders are, of course, part of the community, but most of them only marginally rather than as in some now-classic arguments, as the sole recipients of managerial fiduciary obligations" (Solomon, 1999:46). As mentioned above, the ethical manager must have the requisite willingness to suffer a loss of profits when the conditions for harsh action are not met, when the action envisaged is disproportionate to the end.

In his own contribution to the debate, Deon Rossouw (2003) has questioned whether the principle of double effect can be effectively used in decision making by managers where there would be some negative effects on certain persons. The obvious example would be a decision to lay off certain staff in the interests of greater profitability. While making some interesting points about doing business in countries with poor human rights records, Rossouw's acceptance of the extra-ethical definition of business (value creation) renders this unhelpful for our purposes. According to our understanding, the balancing that must be sought in this kind of ethical reasoning must bring to bear one's sense of moral identity. It is not a question of adding the plusses and minuses in a kind of utilitarian calculation. Rossouw's point is that, "as the purpose of business is value creation, deliberation about double effect should be conducted within the parameters of value creation discourse." He explains:
Although there is no doubt about the moral obligation of business to ameliorate the negative foreseeable side effects of its activities, this obligation must be dealt with in a way that does not undermine the value-creating potential of the business. If the obligation to deal with double effect jeopardizes the sustainability of the business, some trade-off must be found between the obligation of the business to deal with negative side-effects and its quest to remain a sustainability [sic] valuecreating enterprise. (2003:244)

This allows, in other words, for some foreseeable negative side effects that are disproportionate to the ends achieved in the framework of the overall shared moral values of the tradition in which the business is rooted. Such values are, because of the extra-ethical definition of the purpose of business enterprises, systematically disregarded. Rossouw uses a typical utilitarian approach in arguing that the business needs to take into account the interests of the consumers, as well as those of the shareholders (otherwise the consumers will withdraw their support for the business), and even the interests of the environment, in order to bolster its public image. In the kind of reasoning we have been putting forward, in contrast, the reflective process at the same time further advances our understanding of the purpose or end of the social activity, its good. Rossouw's manager manipulates the elements in the situation (including the human factor) through a kind of calculus. Our manager, on the other hand, is called to exercise his or her judgment that (in the difficult cases in question) the foreseen but not directly intended negative effect is proportionate to the gravity of the directly intended (and achievable) end. This deepens the manager's appreciation of what it means to participate in the common enterprise and, through repeated considered acts, builds his or her character.

If we take Rossouw's chosen example, the operations of a business in a country where systematic human rights abuses occur, the decision to continue investing or rather to 
disinvest would seem to be based on summing the value and disvalue defined in terms of isolated individuals. In our model, in contrast, the manager is a participant in a transnational community for which his or her actions carry a meaning, and the willingness to suffer a loss of profits could confirm the company's intentions as just. The expressive meaning of disinvestment, refusing a 'business-as-usual' attitude, and overriding considerations of economic benefit alone to the poorer members of the country might spark the necessary courage for the people to resist the regime. If the firm disinvests (for example), the unintended but foreseen negative effect (a negative impact on the GNP) should be proportionate to the end (achievable, in part, through its expressive meaning of support for the victims) of a more just society.

\section{CONCLUSION: AN ETHIC OF RESPONSIBILITY}

I want to conclude by giving an example of how 'pragmatic' the ethics of proportionalism, in fact, is. It ultimately amounts to an ethic of responsibility. It can be usefully contrasted with the more principled approach of another writer in the Thomistic-Aristotelian tradition, Germain Grisez. In his discussion of the ethics of lying, Grisez uses the example of someone asked to identify children for deportation to a death camp. Here, he says, one should "resist injustice by every morally acceptable means", but, as Julia Fleming comments, those means do not, for Grisez, include lying.

Not only does every lie involve self-alienation, in Grisez's view, but in these circumstances, lies produce deleterious consequences. Lying to the representatives of a totalitarian power 'maintains a semblance of community based on false ideology and blocks the development of real community based on the common good'. In other words, the liar [argues Grisez] evades danger without confronting the situation which created it, rather than creating an opportunity for the aggressors' conversion and for eventual social change. (Fleming, 1999:64)

Here, the difference from our proportionalist approach is evident: in disregarding the Just War requirement of there being a reasonable possibility of success, Grisez reveals his approach as one of principles, rather than one of responsibility. One might argue that, of course, you never can tell; one's action might, against all odds, have the required effect - and, indeed, Grisez points to an example where this seemed to have been the case. However, the expressive meaning of the betrayal of letting an innocent person die (in the death camp) would, in our approach, outweigh the expressive meaning contained in the telling of a lie. If the likelihood of success in getting the aggressor to be stirred into reflection and a change of heart, and, in turn, having a significant effect on the broader society of which the aggressor is a member, seems small, then the principles of justified war would preclude one from telling the truth.

In conclusion, I can note that this guiding notion of being responsible would get its meaning from the moral narrative of which one is a part, and, contrary to Rossouw's implicit assumption, moderates the norms attached to any profession or business enterprise. Moral reasoning, I have argued with the help of Spaemann, takes place within the moral ambit of a common commitment to respecting persons, and being a conscious participant in this moral community is not at all a matter of being a 'club member' over and against other clubs or moral communities. In other words, this kind of foundational ethics is not disqualified in multicultural societies. Contrariwise, seeing business ethics simply in terms of abstract moral principles or codes of ethics will probably mean systematically overlooking the crucial ethical questions to do with building community through attitudes that include commitment and reconciliation. To make my point, I have drawn on a somewhat unusual range of evidence not normally thought of as having direct relevance to our topic. If the argument developed here is sound, business 
ethics could well benefit from paying greater attention to this rearticulated Aristotelian tradition of proportionalist moral reasoning. The character of the business manager - the quality of his or her participation in the moral community - does indeed matter, and character is formed through acts of considered prudence.

\section{REFERENCES}

Anscombe, G. E. M. 1958. Modern moral philosophy. Philosophy, 33:1-19.

Aquinas, St Thomas. 1993. Commentary on Aristotle's Nicomachean ethics. Translated by C. Litzinger. Notre Dame: Dumb Ox Books.

Aquinas, St Thomas. 1948. Summa theologica. Translated by Dominicans of the English Province. Allen, Texas: Christian Classics.

Aristotle. 1954. Nicomachean ethics. Translated by Sir David Ross. London: Oxford University Press.

Bennett, C. 2003. Personal and redemptive forgiveness. European fournal of Philosophy, 11(2):127-144.

Brytting, T. 2002. From institutional context to personal responsibility. In J. Verstraeten (Ed.), Business ethics. Broadening the perspectives. Leuven: Peeters.

Carney, M. 2014. Inclusive capitalism. [Online] Available: http://www. bankofengland.co.uk/publications/ Documents/speeches/2014/ [Accessed 20 August 2014].

Catacutan, R. 2013. Education in virtues as goal of business ethics instruction. African Journal of Business Ethics, 7:62-67.

Clark, M. 2002. In search of human nature. London: Routledge.

Covey, S. 2004. The 7 habits of highly effective people. Simon and Schuster.

Cruddas, J. 2012. The role of the state in the good society. New Statesman. [Online] Available: http://www.newstatesman. com/politics/cruddas [Accessed 20 August 2014].
Fleming, J. 1999. The ethics of lying in contemporary moral theology: Strategies for stimulating the discussion. Louvain Studies, 24:57-72.

Frankfurt, H. 1993. On the necessity of ideals. In T.Wren \& G. Noam (Eds.), The moral self. Cambridge, Ma.: MIT Press, 16-27.

Garcia, J. 2003. Modern(ist) moral philosophy and MacIntyrean critique. In M. Murphy (Ed.), Alisdair MacIntyre. Cambridge: Cambridge University Press, 94-113.

Giddy, P. 2000. A critical ethic of transformation: Dialogue with Marx and Aristotle. Theoria, 95:79-93.

Giddy, P. \& Detterbeck, M. 2005. Questions regarding tradition and modernity in contemporary amakwaya (choral) practice. Transformation, 59:26-44.

Giddy, P. 2010. Attention, people of earth! Aristotelian ethics and the problem of exclusion. South African fournal of Philosophy, 29:357-372.

Gini, A. \& Sullivan, T. (Eds.). 1989. It comes with the territory. An inquiry concerning work and the person. New York: Random House.

Hoose, B. 1987. Proportionalism. The American debate and its European roots. Washington, D.C.: Georgetown University Press.

Hunter, I. 2000. Is metaphysics a threat to liberal democracy? Theoria, 95:59-78.

Jacobs, J. 1994. Systems of survival: A dialogue on the moral foundations of commerce and politics. Vintage.

John-Paul II. 1993. Veritatis splendor. Boston: St Paul's.

John Templeton Foundation. 2008. Does the free market corrode moral character? [Online] Available: http://www. templeton.org/market [Accessed 20 August 2014].

Kalbian, A. 2002. Where have all the proportionalists gone? fournal of Religious Ethics, 30:3-22.

Kwant, R. C. 1969. Sociale filosofie. Utrecht: Het Spectrum. 
MacIntyre, A. 1979. Corporate modernity and moral judgment: Are they mutually exclusive? In K. Goodposter \& K. Sayre (Eds.), Ethics and problems of the twentyfirst century. Notre Dame: University of Notre Dame Press.

MacIntyre, A. 1981. After virtue. London: Duckworth.

Macmurray, J. 1960. Persons in relation. London: Faber.

Madigan, A. 2010. Review of Spaemann's Persons. Journal of Religious Ethics, 38:373-392.

Marx, K. 1964. The economic and philosophical manuscripts of 1844 (Ed. D. Struik). New York: International.

McCloskey, D. 2006. The bourgeois virtues ethics for an age of capitalism. Chicago: University of Chicago Press.

Menkiti, I. 1979. Person and community in African traditional thought. In R. Wright (Ed.), African philosophy. Washington, D.C.: University Press of America.

National Conference of Catholic Bishops. 1986. Economic justice for all. Pastoral letter on Catholic social teaching and the US economy. Washington, D.C.: United States Catholic Conference.

Oyowe, O. A. 2013. Strange bedfellows: Rethinking ubuntu and human rights in South Africa. African Human Rights Law fournal, 13:103-124.

Rossouw, D. 2003. Business is not just war. Transferring the principle of double effect from war to business. South African Fournal of Philosophy, 22:236-246.

Schumacher, E. F. 1973. Small is beautiful. Abacus. Sen, A. 2009. The idea of justice. Penguin.

Singer, P. 1999. Reflections. In J. M. Coetzee, The lives of animals. New Haven: Princeton University Press, 85-92.
Solomon, R. 1992. Ethics and excellence. Cooperation and integrity in business. New York: Oxford University Press.

Solomon, R. 1999. A better way to think about business. How personal integrity leads to corporate success. Oxford: Oxford University Press.

Spaemann, R. 1996. Is every human being a person? Translated by R. Schenk, O.P. The Thomist, 60:463-474.

Spaemann, R. 2006. Persons. The difference between 'someone' and 'something'. Translated by O. O'Donovan. Oxford: Oxford University Press.

Toulmin, S. 1990. Cosmopolis. The hidden agenda of modernity. Chicago: University of Chicago Press.

Tugendhat, E. 1993. The role of identity in the constitution of morality. In T. Wren \& G. Noam (Eds.), The moral self. Cambridge, Ma.: MIT Press, 3-15.

Velasquez, M. 2006. Business ethics. Concepts and cases. 6th ed. New Jersey: Pearson Prentice Hall.

Ver Eecke, W. 1975. The look, the body and the other. In D. Ihde \& R. Zaner (Eds.), Dialogues in existential philosophy, Vol. 5, 224-246.

Verstraeten, J. 2000. Business ethics and personal moral responsibility. In J. Verstraeten (Ed.), Business ethics. Broadening the perspectives. Leuven: Peeters.

Woermann, M. 2012. Review of the second annual Ethics SA conference: An investigation of the state of ethics in South Africa. African Fournal of Business Ethics, 6(2):88-92.

Zaborowski, H. 2010. Robert Spaemann's philosophy of the human person: Nature, freedom and the critique of modernity. Oxford: Oxford University Press. 